\title{
HISTORY OF THE FRENCH NOTARIAL SYSTEM.
}

In France every attempt to transfer any right or title to real property brings the parties into contact with a public functionary who has no counterpart in the federal or state officialdom of this country. His title is "Notary." He has a professional and social standing all his own. His dignity is derived from his appointment by the President of the French Republic; his integrity is assured by ample bond given for the faithful performance of his duties; and the respect and esteem of his fellowcitizens arise from the fact that he plays an important role in almost every phase of the life of individuals from the cradle to the grave.

To conceive even a most general idea of his office by using parallels in our own institutions one must group all or some part of the duties and functions of the old-time family lawyer, the former conveyancer or scribe whose vocation was that of drawing up legal instruments and passing upon titles to real property before the days of title and trust companies, recorders or registrars of deeds and mortgages, registrars of wills, or surrogates, notaries public, masters in chancery, commissioners of deeds, investment agents, collectors of rents and other income, masters in partition, arbitrators, guardians, administrators, custodians of vital statistics, depositaries of public records, court clerks and other officials connected with the daily routine of men's affairs too numerous to be detailed here.

The office of Notary is older than any other now connected with administration or jurisprudence in France. Like many other features of the laws and government of that country it has retained traces of Roman origin. It cannot be said, however, that the Romans had any public functionary whose duties were the same as the modern Notary. In the earliest times there were public slaves, who fulfilled the role of scribes in taking notes of proceedings between individuals and preparing agreements for parties and, in certain cases, entered into stipulations for them by 
their authority. Later these scribes exercised a distinct and recognized vocation and were known as tabelliones, but their activities were of a purely private nature. They were still largely of the slave class, although many were voluntarily rendered freemen by their masters. Their services in time became more intimately connected with public and private affairs. This led to their separation into two groups, called tabularii and tabelliones. A tabularius was a municipal officer who kept the public accounts and became the custodian of archives and documents. Originally he was always a slave but in course of time was manumitted with the restriction of being unable to resign his office. In the year of Rome 40r, all tabularii were made absolutely free. Their official intervention was necessary concerning declarations of birth, liberation of minors, inventories of the property of incapables, witnessing wills of the blind, inventories of decedent's estates, declarations of heirs, \&c.

The tabelliones performed services more akin to those of modern notaries. They were merely an advanced class of ancient scribes and acted for private parties in the drawing up of various documents. - Their field became enlarged gradually as the jurisprudents could no longer perform all the services which formerly had belonged to their calling. They had been sought for the drawing of legal papers (cavere), for legal advice (respondere) and for appearing as counsel in actual litigation (agere). The first they in time diverted into the hands of the tabelliones and by the second century the latter were a distinct and honored class. Their instruments became known as acta forensia because by Justinian's novel 44 they were assigned a statio in the forum where they were authorized to attend to their affairs and meet their clients. They formed a college or corporation and had the definite professional standing. Each one had clerks, called cursores, logographi, or notarii, who were so named because they noted down in brief signs the substances of conferences and drew up a scheda, or schedule, of the facts agreed upon from which the convention was subsequently drawn in full form and certified by the tabellion. That became the complexio contractus recognized by the law. The instrument, 
however, could not be made authentic by the tabellion alone, for it had to be presented in the presence of two witnesses to the magister census and receive the public seal before it could become self probative and therefore legal evidence. By this the acts which were merely scripturae forenses became scripturae publicae. Later in the Eastern Empire all instruments had to be drawn up on paper procured through the fiscus or they could not be authenticated. By novel 47 of Justinian the act was required to contain certain initial and final formalities of phraseology. All of these phases are dealt with in the novels from 44 to 75 . The institution of the tabellionate, with some modifications, was extended to lower Gaul and other well-settled centers of Roman provincial life, but was obliterated practically throughout Europe by the barbarian invasion. Like other Roman institutions only vague traditions and rare material fragments survived the havoc of the conquest. During those centuries when Europe was re-adjusting itself such documents and acts as were occasionally put in writing in that unlettered age were prepared by chance persons who possessed the necessary education, mainly monks and priests. In the north these unofficial scribes were called cancellarii from their combining the religious calling with matters of such public importance as to require the writing of documents, but in the south the Roman tradition was strong enough to cause them to be called notarii. This name gradually became common to both the pays de droit écrit and the pays de droit coutumier. In the name the Roman revival is seen to have overthrown at least the feudal terminology. On the other hand, feudalism left a most important impression upon the notariat which to some extent still exists, viz: its dual jurisdiction in which the gracious is intimately connected with the contentious. In the center and north of France the title of Notary indicated employes of the Royal Chancellerie, called "Notaries of the King" and also the scribes attached to the royal seigniorial and communal courts of justice to keep records of the proceedings. One of their duties was also to prepare and keep a minute in writing of all sorts of private agreements. Thus the contentious and gracious jurisdictions were concentrated in the same hands. This was a dis- 
tinctly feudal element, for it arose from the recognized doctrine that whoever possessed judicial power as sovereign or vassal could delegate it in any form. Consequently even communes that held autonomous charters appointed municipal magistrates with judicial and notarial functions or designated "notaries public" to act in conjunction with the courts of justice.

The first official recognition of these notaries after the conquest is found in the capitulary of 803 of Charlemagne, in which he directed his missi dominici to institute notaries at the various seats of delegated government they were sent to establish or supervise. In 805 , this sovereign example was followed by many greater lords and bishops. No regularity, however, seems to have marked such appointments whether royal, seigniorial or ecclesiastical; and notarial functions fell into a merely utilitarian state, guided largely by the exigencies of time or place and dependent upon the caprice of courtiers, lords or bishops. The two duties, however, of acting as scribes for private parties and keeping the records and drawing up decrees of courts of justice seem to have been performed, and the vocation was still confined to men of the Church. In 962 , Otto I announced a "decision" that shows some attempt to regulate the calling. $\mathrm{He}$ authorized any one of the personnel constituting the chancellerie of each bishopric or metropolitan church to draw up acts and conventions for private parties. This was a measure partly of convenience and partly of conciliation. The ecclesiastical authorities had long employed scribes for Church affairs and they were known as apostolic or official notaries. They were appointed by the popes and acted as secretaries to the bishops with the duty of drawing up documents in which the Church was interested. They had no civil status, but by sophistical extension of the interests of the clergy they so frequently invaded the jurisdiction of the civil notaries and tabellions as to arouse complaint. To give order to this dissension Otto I. recognized to a certain extent the right of ecclesiastical notaries to act in civil matters, but his. "decision" in no way limited the powers of the civil appointees. This conflict between the two jurisdictions arose largely from the fact that all notaries in the earlier 
period were clerics, and it continued until the profession was laicised in the fifteenth century. For two centuries after the placation order of Otto $I$, nothing in the way of general royal regulation appears to have been officially attempted; but, while legislation was silent, worldly affairs went on and there accordingly grew up an irregular institution of notarial services in connection with the royel parliments or courts of justice and the territorial courts of the lords and bishops that by custom became quite generally recognized. Under the impulse of creating offices certain clerks were appointed to draw up the decrees of court and also agreements of parties, and other officials were appointed to certify to their correctness and give them authenticity. The former were called notaries and the latter tabellions-a name doubtless revived from the Romans by the churchmen, who alone seem to have retained a knowledge of the former imperial institutions. It was in the south of France, however, that the tabellions were first revived and their acts were invested with full authenticity giving them complete probative and executory force. Two registers were kept, one called the "manuale notarum," in which the facts or notes were entered as given by the parties, and the other "le livre d'étendues," containing an elaboration of the notes and constituting the legal act or minute. In some of the lesser seigniories and subaltern jurisdictions the notarial functions were absorbed entirely by tabellions. The tabellionat, however, was not inaugurated at Paris. There the notaries delivered all papers en brevet; that is, the actual document, all of which had to be in the handwriting of the notary and by him duly certified, and he kept no minutes. In the provinces it was otherwise. The minute was kept and the tabellion, after the minute had been prepared by the notary or himself, certified to the copy of it or to the authenticity of the instrument itself. This was the situation when, in 1270, Louis IX appointed sixty royal notaries for Paris to be attached to the jurisdiction of the Chắtelet under the Provost of that city. The Chătelet had been the ancient dwelling place of the counts of Paris before the County of Paris was united to the crown by Hugh Capet in the tenth century. There the Royal Parliament, 
when not elsewhere with the King, met and exercised its legislative and judicial functions, the latter being under the supervision of the Provost, and all royal legal matters being there conducted.

Notaries were also appointed for the King's appendant territories, but their jurisdiction was limited to those territories, while the acts of the royal notaries of Paris, from the first, and later those of Montpellier and Orleans, ran throughout France.

The appointment of the Paris notaries by Louis IX was the beginning of the modern notariat, for from that time more definite measures were adopted looking to the stability of the profession and the regularity of the functions. In 1302 and 1304 , Philip IV, historically known as "le Bel," as a part of his work of concentrating all sovereign powers in himself and creating a real French monarchy, ordained that his Parliament, which formerly followed the King, should become fixed at Paris, confirmed the privileges of the Paris notaries who had already become a college or corporation, made the office perpetual, although until then it had been held at the pleasure of the King, and also prescribed certain rules that notaries should follow in drawing instruments and made them responsible for errors. It was by his ordinance of July, r304, that the honoraria, or recompense for notarial services, was first officially and definitely recognized, although according to Loyseau it had existed by custom from the earliest times. Louis $\mathrm{X}$, in I3I5, confirmed the right and subsequent royal edicts firmly establishing the doctrine that notaries should be paid by the parties interested in all acts passed before them. Like Louis IX he appointed only churchmen to the office and this custom continued for more than a century afterwards. Documents accordingly continued to be couched in a crude latin, while the spoken language of France consisted of much Celtic, some German and a great amount of vulgar latin affecting irregularly whole words or merely pronunciation. There were as many dialects as principalities, France having no common tongue. Under Philip le Bel in the early part of the fourteenth century the great princes were induced to surrender some of their arrogant privileges and rally about a 
central standard and royal court at Paris. A species of nationalism became apparent and both governmental and individual affairs caused more frequent journeys of inhabitants to the capital. This continuous and increasing commingling of the people from distant provinces and the promulgation of measures applicable to all parts of the realm constituted the starting point of a real French nation and a national language. The example of Philip in defining the duties and responsibilities of notaries and the appointment of them in all parts of his princely and royal domains was followed by the lesser lords, both lay and ecclesiastical. There was some conflict, however, between those so appointed and the tabellions who had become recognized by custom. Accordingly Philip V, known as "le Long" or "Tall," - in 1319 , by ordonnance defined the difference between notaries and tabellions, whereby the latter were recognized as local functionaries and the former as officials of governmental centers or the jurisdictions of the parlements. Then followed a century of comparative royal inactivity on the subject, although custom continued to exercise its formative force. In the provinces acts had formerly been drawn in the names of the parties with the names of witnesses at the end, followed by the certificate of notary or tabellion with a small personal seal. These features were modified. During the fourteenth and fifteenth centuries the seal became a specific design, founded upon the initial of the tabellion's name as a central idea. At about the same time the form of the act was changed to a declaration by the notary in the form of a recognizance closing with the announcement of his seal. These changes, however, were not marked among the Paris royal notaries, who continued to write all instruments in their own hand and had no seal. Indeed it was not until 1437 , that they began to keep minutes of their acts, which they had theretofore always delivered en brevet. There were some steps taken during this period that affected the scope of notarial activity, arising out of the disposition to multiply officials, but the Paris and other central royal notaries were not affected. Besides recognizing the exclusive right of tabellions to deliver exemplifications or "grosses" of acts received "en minute" by notaries, there was 
created the office of garde-notes, whose duty consisted in conserving the minutes of notaries who had died or resigned, and also the office of "garde-scel," who sealed the exemplifications or certified copies of minutes delivered by the tabellions. These new officers, however, as before stated, were not appointed in Paris, but acted in the princely jurisdictions of the Crown or the territories of lords and bishops.

During the early part of the fifteenth century an important change took place concerning the personnel of the royal notaries. Charles VII ordained that they need not be clerics as theretofore required, but that the appointment should also be open to laymen. Later in the same century Charles VIII excluded the clergy absolutely and thus laicised a profession that had belonged to churchmen from the time of Charlemagne. The next forward step was to sweep away the last remnant of the clerical relation to the office. In $I 539$, Francis I ordained that all acts and documents should be drawn up in the French language, that candidates for the royal notariat should demonstrate mental and moral qualifications and that their acts should be executory throughout France. These were measures which social and economic conditions made imperative. Europe had shaken off the sloth and ignorance of centuries under the impetus of the Reformation and the Renaissance. Commercial enterprise called for notarial services as never before and the integrity and ability of the notariat, as well as the executory force of public acts, became of prime importance.

This increase in the demands upon the notarial services brought about what is considered as the great landmark of the profession. Up to this time every royal notary was obliged to write every document and perform every act with his own hand and in his own proper person. It became practically impossible for the Paris notaries to do this owing to the great increase of affairs. Then Francis I by ordonnance of September I, I54I, authorized the employment of clerks for all engrossing and making of notes and minutes under the supervision and certification of the notary. This was the beginning of what is known as the "Basoche du Notariat," or corporation 
of clerks of the notaries of Paris, which has ever since been recognized as a preparatory and disciplinary body from which the profession draws its members.

The effect of the importance, definite functions and corporate force of the Company of Notaries at Paris was felt throughout France and had a tendency to circumscribe the performance of notarial duties by others, set the example of forms and procedure and particularly showed the incongruity of the provincial tabellionat and its appendages. Accordingly we find that Henry II, by edict of October 4, I554, forbade judges, lieutenants and court clerks from performing any notarial act or receiving the declarations of contracting parties. This was followed, in 1560 , by an ordonnance requiring the signatures of parties and witnesses to acts as was customary in Paris.

Finally Henry IV, in I597, united the offices of tabellion and garde-notes to that of notary, which he made hereditary and saleable. The office of garde-scel subsisted until I706, when Louis XIV made it compulsory for all notaries to have a seal containing the royal arms and to attach it personally to all their official acts. This applied to all notaries who, outside of Paris, had until then been obliged to obtain the seal of the court to whose jurisdiction they were attached. The remaining provincial and seigniorial tabellions were subject to the same necessity. These were not many, however, for except in some parts of the south, where custom had become law, in certain autonomous municipalities and isolated feudal grants that had not been surrendered to the Crown, the tabellions had given place to notaries in accordance with the successive royal ordonnances. At last, in 1761 , the functions of all tabellions were transferred to notaries by Louis XV. In I78I, Louis XVI promulgated a law in which the entire subject was codified and regulations made for the entire notariat of France, except in the territory of the Duke of Orleans and a few other principalities where the feudal powers remained unabridged. The new law, however, was in many respects adopted even by them. This final solidification of the system caused to be accepted generally throughout France all of the attributes of the royal notaries 
as to forms and procedure, no matter from what power the office was derived. Accordingly on the eve of the Revolution the notariat had an acknowledged place in public affairs and was then exercised by (I) royal notaries; (2) seigniorial notaries; (3) apostolic notaries, appointed by the popes for authentication of such temporal matters as the interests of the Church might require to be sent to Rome; and (4) municipal notaries, appointed under the charter privileges of certain cities.

Their recognized functions were those of public officers of high probity authorized to receive directions from parties and prepare their acts and contracts, to give them validity, certain date, preserve them on deposit and deliver exemplifications and certified copies of them as required. The records of their offices, embracing their own activity and that of their predecessors, constituted the muniments of title to real property, evidences of marriage settlements and wills of many generations, in their several jurisdictions. They had become the trusted counsellors of their clients and often served as amiable arbitrators in their differences. They gathered their last wishes in testamentary form and afterwards regulated the rights of the heirs. They aided in investments and advised how to repair the errors of business judgment. In fact, few affairs of life or death could be regulated without recourse to some member of the notariat.

While the Constituent Assembly was uprooting the feudal system, suppressing the Bar and reorganizing the courts, it was also endeavoring to reconstitute a new working government. In I791, by the law of September 27th-October 6th, all notarial officers were suppressed and their venality and heredity abolished, but by the same law a new notariat 'was instituted. Articles I and 2 of Section II provided:

Art. I. "There shall be established in all the realm public functionaries charged to receive all the acts which are now within the jurisdiction of the royal and other notaries and to give them the authentic character attributed to public acts."

Art. 2. "Those functionaries will bear the name of public notaries, shall be instituted for life and shall not be deprived of office except for bad conduct first judicialiy determined." 
By other articles all notaries were formed into one body, every member of which was vested with identical powers, all special privileges, such as had formerly been enjoyed by those of the Châtelet, were withdrawn and each was restricted in the performance of official acts to the department of his residence. One of the provisions that did receive a moderate amount of consideration in the debate was that relating to the honorarium, the result being a recognition of the principle as already settled and the adoption of measures regulating it. It is clear, however, that the law of I79I was hastily drawn and that its provisions were purely utilitarian. Its operations were not foreseen and its inadequacies soon made further legislation necessary. It was particularly defective in not clearly declaring whether notaries should be considered as still having duties pertaining to the jurisdiction of litigation, and contrary interpretations left the question in doubt. For the next ten years efforts were frequently made by laws and decrees to remedy the defects and also to reiterate constantly the passing of the old régime. One of the notable laws of this period was that of the 8 pluviôse, year II, which declared: "All notaries, clerks and other depositaries whomsoever are forbidden to insert in the future in the minutes, copies or extracts of acts of all nature, whateveI may be their date, clauses, qualifications, enunciations or expressions tending to recall in a manner direct or indirect the feudal or noble régime or royalty under penalty," \&c. Then under the master hand of Napoleon the law of 25 ventôse- 5 germinal year XI (16-26 March, I803) was passed embracing the whole subject and establishing the bases of the modern notariat. It was one of the first fruits of the efforts to reconstruct the civil institutions that had been destroyed by the revolutionists. Its preparation and discussion proceeded with the projects of the codes of laws that were adopted soon after it. The reported debates upon its various articles in the Council of State reveal rich historical matter and a high degree of foreseeing reason. It is clear that the legislators deemed the measure of first importance, even beyond the adoption of the civil code. It constitutes an orderly resumé of the formative steps of several centuries, together 
with definite provisions for an organization suitable to existing conditions and the probable need of future modification. The draftsmen did not reject principles because they were ancient, nor because of their feudal, provincial, customary or Roman origin. They recognized that they were reorganizing an institution older than French national history and more closely allied to the individaul affairs of citizens than any department of government. They did not repeal even some of the provisions of the law of I79I. Upon the most radical feature, however, there was no difference of opinion; all agreed that the new organization should be entirely separated from the contentious jurisdiction of justice. Said Toullier (t. 6, 2II), one of the most revered of French commentators, referring to both the laws of 1791 and 25 ventôse: "Those laws worked a remarkable change in the nature of the functions of notaries. They are now the direct and special delegates of the executive power to render executory all acts and contracts, the parties to which ought or wish to have the authentic character of acts of the public authority. Their authority is no longer, as it was formerly thought to be, an emanation of the judicial authority, but an immediate delegation of the executive power."

Some idea of the scope of the act is to be gained from the remarks of Monsieur Réal when he was explaining it to the Council of State. Said he: "Tranquility calls for other functionaries, who, while disinterested counsellors of parties, are also the impartial draftsmen of their wishes, making known to them all of the effects of the obligations they undertake, drawing up their contracts with clearness, giving to their acts the character of authenticity and the force of a judgment in last resort, perpetuating their memories and preserving with fidelity their deposits of documents, preventing differences from arising between men of good faith and depriving unscrupulous men of the hope of succeeding by unjust contests. Those disinterested counsellors, those impartial draftsmen, that species of voluntary judges who irrevocably bind contracting parties, are the notaries: that institution is the notariat."

In order to better understand the provisions of the law it should be borne in mind that the primary object was to give 
notaried acts the character of governmental authenticity; that is, make them self-proving and self-executory without reference to or aid from the judicial or other department. In French law there are four kinds of authentic acts: 1 . The legislative; 2 . The administrative; 3. The judicial, or contentious, and 4 . The gracious, or voluntary, $i$. e., the uncontentious. To this last class belong the acts of notaries and these only are the subject of the law of 25 ventôse now about to be considered.

Art. I. "Notaries are the public functionaries established to receive all acts and contracts to which the parties must or wish to invest with the character of authenticity attached to acts of the public authority, and to assure the date of them and to keep them on deposit and to deliver exemplifications and certified copies of them."

Art. 2. "They are instituted for life."

Art. 3. "They are obliged to lend their ministry whenever they are required."

Art. 4. "Each notary must reside in the place indicated for him by the government."

Art. 5. "Notaries will exercise their functions as follows:

Those of cities where a tribunal of appeal is located, throughout the territorial jurisdiction thereof.

Those of cities where there is only a tribunal of first instance, throughout the territorial jurisdiction thereof.

Those of communes, throughout the territorial jurisdiction of the justice of the peace thereof."

Art. 7. "The functions of notaries are incompatible with those of judges, court commissioners, court clerks, counsellors, bailiffs, tax collectors, justices of the peace, police commissioners and commissioned auctioneers."

Art. 9. "The acts shall be received by two notaries, or one notary in the presence of two witnesses, French citizens able to sign and residing in the communal district where the act is passed." 
Art. 13. "The acts of notaries shall be written in a continuous context, readable, without abbreviation, blank, lagoon or interval; they shall contain the names and surnames, business and residences of the parties as well as the witnesses * * *."

Art. I4. "The acts shall be signed by the parties, the witnesses and the notaries, who must mention that fact at the end of the act. As to parties who do not know how or are unable to sign, the notary must mention at the end of the act their declarations in that regard."

Art. I9. "All notaried acts shall be received in courts and shall be executory throughout the Republic. Nevertheless in case of complaint of forgery the * * * tribunals may, according to the gravity of the circumstances, temporarily suspend the execution of the act."

Art. 20. "Notaries shall keep a minute of all acts they receive. Nevertheless this provision shall not apply to certificates of life, powers of attorney, acts of notoriety, discharge of farm leases, rentals, salaries, arrearages of pensions and income and other simple acts which, according to law, may be delivered en brevet."

Art. 2x. 'The right to deliver 'grosses' and 'expeditions' shall belong only to the notary holding the minute; nevertheless every notary may deliver a 'copie' of an act that may have been deposited with him for minute."

In explanation of these words it may be said that a "grosse" is a literal copy of the minute with the declaration or certificate of the notary, giving the instrument executory form. If it should be a lease containing a clause of surrender at a day certain, that time having expired, the notary would make it executory and any bailiff could dispossess the tenant under that authority. If the "grosse" is of an obligation to pay a definite liquidated sum on a certain day, and that day has expired, the 
creditor obtains execution by securing the "grosse" and lodging it with a bailiff, who is then authorized to levy on all the property of the debtor save real estate, which is subject to certain other requirements under Article 556 of the Code of Civil Procedure. An "expedition" is merely an exact copy of the minute and is often merely to be offered in evidence in a pending litigation. It proves itself. Every "grosse" is an "expedition," but no mere "expedition" can be "grosse." An "extract" is often used for the same purpose as an expedition, but need not be the entire instrument entered in the minute. A "copie" means an entire reproduction of an act or instrument deposited for the purpose of having a minute made of it. Many acts entered into between parties privately over their own signature are thus deposited as one would lodge a deed or agreement with a recorder in this country.

Art. 23. Provides that communication of acts shall be made only to interested parties and imposes professional secrecy. This was later emphasized by Article 378 of the Penal Code.

Art. 25. "The grosses only shall be delivered in executory form; they shall be entitled and terminated in the same terms as the judgments of the tribunals.";

The language of the mandate of execution is as follows:

French Republic.

In the Name of the French People.

(Then is inserted the full transcript of the act.)

"In consequence the President of the French Republic commands and orders all bailiffs by this required to put these presents in execution; to the procurers general and to the procurers of the Republic attached to the tribunals of first instance to there hold the hand; to all commanders and officers of the public force to lend assistance whenever they shall be legally required."

Art. 27. "Each notary shall have a particular seal containing his name, official character and residence, and a design of the French Republic, according to a uniform type:- The 
grosses and expeditions of acts shall carry the imprint of that seal."

This has been modified under the third Republic by adoption of a State seal containing a statue of liberty, which all public officials are required to use.

Art. 28. Provides that all acts that are to be used or executed outside the jurisdiction of the notary who received them must have his signature legalized by a judge of the court of first instance of his territory. The acts then become executory throughout France. It is a doctrine that legalization confirms authenticity, but does not constitute it. (Rolland de Villargues, "Légalisation," 2.)

Art. 29. "Notaries shall keep 'répertoire' of all acts that they receive."

Art. 30. "The 'répertoires' shall be examined and each item marked by the president $* * *$ of the civil tribunal of the residence. They shall contain the date, nature and species of the act, the names of parties and the relation of the act to the government stamp tariff."

Both of these articles in using the word "répertoire" indicate a general daily journal, or register, in which are set down all transactions of the office in chronologicel order, indicating whether the act was a sale, release, will, \&c., and also whether it was delivered en brevet or as a "grosse," "expédition" or "copie." The final paragraph, as well as the necessity of the visé of the judge, is to protect the public treasury as to stamp duties, which in France are imposed to a degree that sometimes becomes ludicrous. Certain it is, in any event, that from an ordinary receipt for a merchandise bill to a conveyance of land the fiscus levies toll.

Articles $3 \mathrm{I}$ to 34 , inclusive, regulate the number and location of notaries and the bonds they must give for the faithful performance of their duties. The number is regulated by the government and determined by the extent of population. In Article $3^{2}$ it is provided that "the suppression or reduction of places shall result only from death, resignation or dismissal for wrongdoing." 
Articles 35 to 49 , inclusive, regulate the qualifications of candidates and the manner of their appointment. The principal requirements are that they shall be in the free exercise of citizenship, have completed their military service, be twenty-five years old, have served six continuous years as first clerk to a notary, present a certificate of morality and capacity from the Chamber of Notaries of the district in which appointment is sought and that the appointment is made by the chief executive of the State. By Articles 46 and 47 the commission is addressed to the tribunal of first instance and the appointee there takes his oath of office after exhibiting his commission and a certificate that he has entered his bond. By Article 49, before acting officially, he must deposit with the clerk of the court his signature and his initial as he will employ them in signing acts and verifying marginal notes thereon.

Articles 50 to 53 , inclusive, relate to the organization of Chambers of Notaries in the several jurisdictions, their disciplinary control of their members and the matter of compensation.

The last was covered by Article 5I, reading as follows: "The honoraria and times of professional service of notaries shall be regulated by amicable arrangement between them and the parties, or otherwise by the civil tribunal of the residence of the notary on the advice of the Chamber and by simple petition without cost."

Thus the ancient theory of no State salary, but fair fees from parties was reaffirmed and perpetuated.

Articles 54 to $6 \mathrm{I}$, inclusive, prescribe how the records of a notary who has died, resigned or been deprived of office for wrongdoing shall be preserved. The office where a notary transacts business has for centuries been recognized as his personal headquarters and become sanctified by the name of "étude" or "study." There all his records are kept, yet they are records of a public official. For that reason upon his death or other cause of disability it is provided that the nearest justice of the peace shall seal the documents until another notary shall take charge under orders from the tribunal in whose jurisdiction the study is located. 
The remaining articles, numbered from 62 to 69 , inclusive, are general provisions intended to adjust existing conditions to the terms of the new law.

Since this fundamental law of 25 nivôse, year XI, there has been additional legislation, but it has largely been in mere amplification of the general principles there laid down, and that well-considered enactment remains the basis of the notariat. The first modifications, if they can properly be so called, occurred when the Civil Code, Commercial Code, Civil Procedure Code and Penal Code were adopted. They contain a few points of contact with the notarial law and in many instances reaffirm its terms. Of course, they control in case of conflict.

The question of fees, however, soon became the object of legislation, and the law of February I6, I807, was passed for the purpose of fixing a schedule of charges. It did not cover the whole ground, for it was found that certain services varied so in nature, responsibility and time required, that no exact rate of compensation could be fixed with fairness. The next step was the law of October I0, $184 \mathrm{r}$, but it was restricted to the subject of judicial sales by notaries of real property ordered by the tribunals. Then followed the law of June 18, 1843, fixing a tariff of charges for acting as special commissioner of seizure on execution; that of February 22, I85 I, relative to contracts of apprenticeship; that of November 5, I85I, concerning auction sales of crops and wood of farm lands, and that of November 9, 1853 , fixing the charges for life certificates of pensioners. During all this period and afterwards there was constant agitation of the question how fees could be made definite, but the subject was not finally put at rest until the law of June 20, I896, and the ministerial decree of August 25, I898, carrying it out. Since that time practically every notarial act has a fixed price that can be ascertained in advance or a definite method by which it can be calculated.

The law of April, I8I6, authorized the presentation of a successor in case of death or resignation, and this has been recognized as a means by which a living notary or his heirs can sell the right to the office. By the laws of April 2I, r836, 
and June 25 , I84I, a tax was imposed upon every transmission of a notarial office. Then the law of June 2I, I843, was passed reorganizing the Chambers of Notaries and defining the disciplinary powers of those bodies. This is still the governing law, although amplified by a Ministerial Circular of March I, 189o, interpreting decrees of January 30 th and February $2 \mathrm{~d}$ of the same year.

The Company of Notaries of Paris, however, was the subject of special laws passed October 26, I846, and April 27, I847, in order to adjust the conditions of such a great center of population to the new general bases. The fundamental principles"relating to the Chambers and their disciplinary powers as established by the law of 1843 were adhered to. For the same reason the tariff law of 1896 , as administered in the decrees of August 25, 1898 , made material differences between the Paris charges and those of other cities and departments.

There have also been general statutory and administrative readjustments from time to time owing to changes in government, but without altering the bases of the system. Many fiscal changes have also occurred affecting the taxation of affairs necessary to be transacted through notaries.

As now constituted the notariat is still divided into three classes, the members in which are appointed to act in the jurisdiction of a court of appeal, the jurisdiction of a tribunal of first instance or the whole or part of a commune where a justice of the peace has jurisdiction. The number in each locality is still regulated by the extent of population and all are subject to the Chambers of Notaries of their own resorts.

The President of the Republic upon recommendation of the Minister of Justice may confer the title of "Honorary Notary" upon whoever has filled the office for twenty consecutive years.

As a body, the notaries of France occupy a place in the public esteem equal to, if not higher, than that accorded any other man or set of men in public office. The disciplinary powers of the Chambers are rarely invoked and malfeasance in office has been practically unknown for the past hundred years. 


\section{BIBLIOGRAPHY.}

Justinian: Nouvelles.

Loyseau: Des Seigneuries.

Rolland de Vill: Rép. du Notariat.

Dalloz: Jur. gén. "Notaire."

Loret: Eléments de la science du Notariat.

Toullier: Droit civil français suivant l'ordre du Code.

Rogier: Etude sur les Tabellions.

Sosthene-Berthellot: Esprit, législation et jurisprudence du Notariat.

Delacourtie et Robert: Discipline des Notaries.

Genty: La Basoche Notariale.

Préel: De la Responsibilité professionelle des Notaires.

Cuq: Institutions juridique des Romains.

Bonnier: Traité des Preuves.

Menguy: Les Actes et Conventions.

Clerc: Manuel et Formulaire du Notariat.

Philadelphia, Pa.

$W . W$. Smithers. 